\title{
HUBUNGAN PENGETAHUAN TENTANG KANKER PAYUDARA DENGAN PERILAKU SADARI (PERIKSA PAYUDARA SENDIRI)
}

\author{
Rini Deska ${ }^{1}$, Dewi Ayu Ningsih ${ }^{2}$, Lisa Luviana ${ }^{3}$ \\ Akademi Kebidanan Panca Bhakti Bandar Lampung \\ email : rinideska12@gmail.com
}

\begin{abstract}
Abstrak
Angka kejadian kanker di Indonesia (136.2/100.000) berada diurutan 8 di Asia Tenggara dan urutanke 23 di Asia. Di Indonesia kejadian kanker lebih di dominasi oleh kanker payudara yaitu 42,1 per 100.000 penduduk. Kanker payudara yang ditemukan pada stadium dini kemungkinaan sembuhnya mendekati 95\%, sehingga pemeriksaan deteksi dini sangat diperlukan. Salah satu program deteksi dini kanker payudara adalah Pemeriksaan Payudara Sendiri (SADARI) . Di tahun 2016, sebanyak 53,7\% masyarakat tidak melakukan SADARI. Penelitian ini bertujuan untuk mengetahui hubungan pengetahuan tentang kanker payudara dengan perilaku SADARI (Periksa Payudara Sendiri) pada mahasiswi AKBID Panca Bhakti Bandar Lampung tahun 2019.Penelitian ini menggunakan desain analitik observasionalmelalui pendekatan cross-sectional terhadap 133 mahasiswa kebidanan. Analisis statstik yang digunakan adalah uji chi-square. Hasil penelitian menunjukan sebagian besar pengetahuan mahasiswa kebidanan dalam kategori baik(43,8\%). Perilaku SADARImahasiswa kebidanan sebagian besar dalam kategori kurang (73,7\%).Secara statistik tidak terbukti ada hubungan antara pengetahuan tentang kanker payudara dengan perilaku SADARI $(\rho=0,420)$. Perlu dilakukan penelitian lanjutan dengan metode eksperimental berupa pre test dan post test tentang efektifitas video dengan prilaku SADARI.
\end{abstract}

Kata Kunci : Pengetahuan, Perilaku SADARI

\begin{abstract}
Cancer incidence in Indonesia (136.2 / 100,000) ranks 8th in Southeast Asia and 23rd in Asia. In Indonesia, the incidence of cancer is more dominated by breast cancer, which is 42.1 per 100,000 population. Breast cancer that is found at an early stage is likely to heal approaching 95\%, so that early detection tests are needed. One of the early breast cancer detection programs is Self Breast Examination (BSE) (P2PTM Ministry of Health, Republic of Indonesia, 2017). In 2016, as many as 53.7\% of the population did not do BSE. This study aims to determine the relationship of knowledge about breast cancer with BSE behavior (Check Breast Self) in AKBID Panca Bhakti Bandar Lampung students in 2019. This study uses an observational analytic design through a cross-sectional approach to 133 midwifery students. The statistical analysis used was the chi-square test. The results showed that most midwifery students' knowledge was in the good category (43.8\%). BSE behavior of midwifery students was mostly in the less category (73.7\%). Statistically, there is no proven relationship between knowledge about breast cancer and BSE behavior $(\rho=$ 0.420). Further research needs to be done with experimental methods in the form of pre-test and post-test about the effectiveness of video with BSE behavior.
\end{abstract}

Key Words :Knowledge, Behavior of Breast Self-Examination

Dikirim: 11 Agustus 2019

Diterima: 21 September 2019

Terbit: 20 Oktober 2019 


\section{PENDAHULUAN}

Angka kejadian kanker di Indonesia 136.2/100.000 berada diurutan 8 di Asia Tenggara dan urutanke 23 di Asia. Di Indonesia kejadian kanker lebih di dominasi oleh perempuan, dengan kanker payudara menjadi kasus terbanyak yaitu 42,1 per 100 . 000 penduduk (Kemenkes RI, 2019). Kanker payudara yang ditemukan pada stadium dini kemungkinaan sembuhnya mendekati 95\%, sehingga pemeriksaan deteksi dini sangat diperlukan (Depkes RI, 2009). Pemerintah telah menyusun berbagai program dalam upaya menurunkan prevalensi kanker payudara. Salah satu program tersebut adalah Pemeriksaan Payudara Sendiri (SADARI). SADARI sebaiknya dilakukan sejak usia 20 tahun atau sejak menikah (P2PTM kemenkes RI, 2017).

Riset Penyakit Tidak Menular (PTM) mencatat masih rendahnya prilaku masyarakat dalam melakukan deteksi dini kanker payudara. Di tahun 2016 terdapat 53,7\% masyarakat yang tidak melakukan SADARI, dan yang melakukan SADARI sebanyak 46,3\%. Di tahun 2017 baru 3 juta wanita usia subur yang baru melakukan deteksi dini kanker payudara (SADANIS) usia 30-50 tahun (2,98\%) (P2TM Kemenkes RI, 2017).

Salah satu faktor penyebab masih tingginya jumlah kasus kanker pada stadium lanjut karena keengganan wanita untuk memeriksakan diri ke dokter. Kondisi ini menunjukkan bahwa masih rendahnya perilaku dalam melakukan SADARI (Kemenkes RI, 2015). Teori Green mengungkapkan bahwa perilaku seseorang sangat dipengaruhi pengetahuan. Pengetahuan seseorang terhadap suatu hal menjadi faktor predisposisi pada perilaku yang akan dilakukan (Notoatmodjo, 2010).

Angrainy (2017) membuktikan bahwa pengetahuan seseorang mengenai SADARI secara statistik terbukti berhubungan dengan perilaku SADARI siswi SMK N 1 Teluk Kuantan $(\rho=0,007)$. Penelitian ini juga membuktikan bahwa $62 \%$ siswi SMK N 1 Teluk Kuantan memiliki pengetahuan yang kurang mengenai SADARI. Penelitian lainnya juga membuktikan bahwa adanya hubungan yang signifikan antara pengetahuan dengan perilaku SADARImahasiswa Kesehatan Masyarakat Universitas Sumatera Utara $(\rho=$ 0,006) (Sari, dkk., 2015).

Berdasarkan studi pendahuluan yang dilakukan penulis terhadap mahasiswa kebidanan AKBID Panca Bhakti, dari 10 mahasiswa, hanya $3(30 \%)$ orang yang sering melakukan SADARIdalam kurun waktu 3 (tiga) bulan terakhir.

Tujuan penelitian ini untuk mengetahui hubungan pengetahuan tentang kanker payudara dengan perilaku SADARI (Periksa 
Payudara Sendiri) pada mahasiswi AKBID

Panca Bhakti Bandar Lampung tahun 2019.

\section{METODOLOGI}

Penelitian ini merupakan jenis penelitian kuantitatif yang menggunakan desain analitik observasionalmelalui pendekatan crosssectional. Penelitian ini dilakukan di Akademi Kebidanan Panca Bhakti Bandar Lampung. Penelitian ini dilaksanakan mulai survey awal sampai dengan penelitian yaitu pada bulan Maret sampai dengan Agustus 2019.

Populasi dalam penelitian ini terdiri dari seluruh mahasiswi Akademi Kebidanan Panca Bhakti Bandar Lampung yaitu 133 mahasiswa. Pemilihan sampel dalam penelitian ini dengan menggunakan teknik stratified random samplingyang terdiri dari 18 orang mahasiswa tingkat I, 20 orang mahasiswa tingkat II dan 19 orang mahasiswa tingkat III. Variabel dependen dalam penelitian ini adalah perilaku SADARI mahasiswa Akbid Panca Bhakti. Sedangkan, variabel independen adalah pengetahuan mahasiswa Akbid Panca Bhakti mengenai kanker payudara. Instrumen yang digunakan dalam pengumpulan data penelitian ini adalah daftar pertanyaan dalam bentuk kuesioner.

Analisis bivariat dilakukan untuk melihat hubungan antara pengetahuan tentang kanker payudara dengan perilaku SADARI dengan menggunakan uji chi-square.

\section{HASIL}

\section{Pengetahuan}

Hasil distribusi frekuensi pada pengetahuan mahasiswa kebidanan Akbid Panca Bhakti Bandar Lampung tentang kanker payudara dapat dilihat pada tabel dibawah,

Tabel 1. Distribusi frekuensi Pengetahuan Tentang Kanker Payudara Pada MahasiswaAkademi Kebidanan Panca Bhakti Bandar Lampung Tahun 2019

\begin{tabular}{ccc}
\hline Pengetahuan & Jumlah & $\%$ \\
\hline Baik & 25 & 43,8 \\
Cukup & 23 & 40,4 \\
Kurang & 9 & 15,8 \\
\hline Total & 57 & 100 \\
\hline
\end{tabular}

Tabel 1 diatas menerangkan bahwa pengetahuan mahasiswi kebidanan Akbid Panca BhaktiBandar Lampung tentang kanker payudara sebagian dalam kategori baikyaitu sebesar $25(43,8 \%)$.

\section{Perilaku}

Hasil distribusi frekuensi pada perilaku SADARImahasiswa kebidanan Akbid Panca Bhakti Bandar Lampung dapat dilihat pada tabel dibawah,

Tabel 2. Distribusi Frekuensi Perilaku SADARI Pada MahasiswaAkademi Kebidanan Panca Bhakti Bandar Lampung Tahun 2019

\begin{tabular}{ccc}
\hline Perilaku SADARI & Jumlah & $\%$ \\
\hline Kurang & 42 & 73,7 \\
Baik & 15 & 26,3 \\
\hline Total & 57 & 100 \\
\hline
\end{tabular}

Tabel 2 diatas menerangkan bahwa perilaku SADARImahasiswa Akbid Panca Bhakti sebagian besar dalam kategori kurang sebesar 42 orang $(73,7 \%)$. 
3. Hubungan Pengetahuan Tentang Kanker Payudara dengan Perilaku SADARI

Analisis bivariat digunakan untuk melihat hubungan antara variabel independen dan variabel dependen dengan menggunakan uji chi square.Hubunganpengetahuan tentang kanker payudara dengan perilaku SADARI (periksa payudara sendiri) pada mahasiswa kebidanan Akbid Panca Bhakti Bandar Lampung dapat dilihat pada table dibawah.

Tabel 3. Hubungan Pengetahuan Tentang Kanker Payudara Dengan Perilaku SADARIPada MahasiswaAkademi Kebidanan Panca Bhakti Bandar Lampung Tahun 2019

\begin{tabular}{lcccccccc}
\hline Pengetahuan & \multicolumn{4}{c}{ Perilaku } & & Jumlah & $\%$ & $\rho$ \\
& \cline { 2 - 5 } & Baik & $\%$ & Kurang & $\%$ & & & \\
Baik & 14 & 29,2 & 34 & 70,8 & 48 & 84,2 & 0,420 \\
Kurang & 1 & 11,1 & 8 & 88,9 & 9 & 15,8 & \\
\cline { 4 - 7 } \multicolumn{1}{c}{ Total } & 15 & 20,2 & 42 & 79,8 & 57 & 100 &
\end{tabular}

Tabel 3 diatas menerangkan bahwa mahasiswi kebidanan Akbid Panca Bhakti Bandar Lampung yang memiliki pengetahuan baik dan melakukanSADARIyaitu sebanyak 14 $(29,2 \%)$ orang.

Tabel 3 diatas juga menerangkan bahwa terdapat sel dengan nilai expected kurang dari 5 (50\%). Oleh sebab itu dilakukan penggabungan sel untuk memenuhi uji kelayakan chi-square. Penggabungan tersebut dilakukan terhadap sel pengetahuan baik dan cukup, karena pada tabel $3 \times 3$ tersebut tidak layak untuk diuji dengan chi-square.. Hasil uji statistik chi-square dapat dinilai p value > dari $\alpha(0,420>0,05)$ yang artinya Ho diterima, tidak ada hubungan yang signifikasi antara hubungan pengetahuan tentang kanker payudara dengan perilaku SADARI (periksa payudara sendiri) pada mahasiswi kebidanan Akbid Panca Bhakti Bandar Lampung Tahun 2019.

\section{PEMBAHASAN}

\section{Pengetahuan Mahasiswa Kebidanan}

\section{Akbid Panca Bhakti Bandar Lampung Tentang Kanker Payudara}

Berdasarkan tabel 1 diatas dapat diketahui bahwa pengetahuan mahasiswa kebidanan Akbid Panca Bhakti Bandar Lampung tentang kanker payudara yaitu sebagian besar memiliki pengetahuan baik yaitu 48 orang $(84,2 \%)$, hanya sebagian kecil yang pengetahuannya kurang tentang kanker paayudara 9 responden $(15,8)$.

Faktor yang mempengaruhi pengetahuan antara lain adalah usia, pendidikan, pengalaman dan informasi. Setelah seorang melakukan penginderaan terhadap suatu objek tertentu maka ia akan memperoleh pengetahuan. Dengan melakukan penginderaan yang baik maka pemahaman seseorang terhadap suatu objek atau informasi akan lebih baik (Notoatmodjo, 2010).

Responden yang mempunyai pengetahuaan baik disebabkaan beberapa faktor yaitu 
responden merupakan mahasiswi kebidanan yang sebagian kecil pernah mendapatkan materi kesehatan reproduksi tentang kanker payudara. Dari hasil kuesioner, sebagian besar responden menguasai tentang pengertian, manfaat dan gejala, tanda dari kanker payudara. Selain itu terdapat fasilitas perpustakaan dan Wifi di kampus Akbid Panca Bhakti yang menunjang mahasiswi mendapatkan informasi.

\section{Perilaku SADARI Mahasiswa}

\section{Kebidanan Akbid Panca Bhakti}

\section{Bandar Lampung}

Pada tabel 2 diatas diketahui bahwa perilaku mahasiswa kebidanan Akbid Panca BhaktiBandar Lampung tentang SADARI sebagian besar memiliki perilaku kurang yaitu 42 orang $(73,7 \%)$.

Perilaku seseorang sangat dipengaruhi oleh pikiran dan lingkungannya. Menurut Benyamin Bloom (1908) dalam Notoatmodjo (2014) pengetahuan, sikap dan tidakan/praktik akan membentuk perilaku seseorang. Perilaku SADARI responden yang kurang dimungkinkan karena pengetahuan responden hanya sebatas tahap tahu dan memahami, belum sampai ke sikap. SADARI adalah pemeriksaan payudara yang dilakukan sendiri,dilakukan setiap bulan pada hari ketujuh sampai sepuluh yang dihitung sejak hari pertama mulai haid (saat payudara sudah tidak mengeras dan nyeri). Atau bagi yang telah menopause pemeriksaan dilakukan dengan memilih tanggal yang sama setiap bulannya. Ada sembilan langkah dalam melakukan SADARI, dengan cara melakukan pengamatan, pemijatan dan perabaan. Pemeriksaan ini bertujuan mengetahui keadaan payudara normal atau mengalami kelainan. Pemeriksaan sesuai dengan langkahlangkah yang benar diharapkan mendapatkan hasil yang akurat (Rasjidi, 2010)

Hasil ini sejalan dengan beberapa peneliti, yaitu pada hasil penelitian yang dilakukan oleh Sari (2017) yang membuktikan bahwa tidak ada hubungan antara pengetahuan dengan perilaku SADARI ( $p$-value=0,380). Penelitian lainnya dilakukan oleh Putri (2011) yang membuktikan bahwa dari 115 responden, sebagian besar responden memiliki sikap yang sedang dan baik terhadap SADARI dengan perilaku yang kurang untuk melakukan SADARI, yaitu sebanyak 87 responden $(77,7 \%)$. Sedangkan responden yang memilki sikap yang kurang dengan perilaku SADARI yang kurang adalah sebanyak 25 responden $(22,3 \%)$.

Banyak responden yang kurang melakukan perilaku SADARI mungkin bisa disebabkan beberapa faktor kemugkinan, diantaranya kurangnya pengetahuan, kurangnya keyakinan, kurangnya kebiasaan, Kurangnya pengatahuan responden tentang pemeriksaan payudara sehingga responden tidak dapat mengaplikasikan secara spesifik tentang langkah-langkah pemeriksaan payudara 
secara lengkap, serta kurangnya dukungan keluarga dalam mensosialisasikan perilaku SADARI, sehingga responden tidak berinisiatif melakukan praktek SADARI. Rendahnya dukungan dalam keluarga dapat mempengaruhi perilaku responden dalam melakukan pencegahan penyakit pada dirinya.

Selanjutnya, kurangnya keyakinan responden untuk bisa melakukan SADARI sehingga responden kurang percaya diri dalam melakukan langkah - langkah pemeriksaan payudara secara lengkap saat praktik secara langsung. Hasil wawancara bebas menurut sebagian besar responden mengatakan tidak yakin bahwa cara pemeriksaan yang dilakukan merupakan langkah yang benar atau tidak.

Faktor ketiga adalah kurang nya kebiasaan dalam melakukan pemeriksaaan payudara, dikarenakan responden malas dalam melakukan SADARI setiap bulannya. Sehingga perilaku SADARI lama - lama menjadi hilang dan responden tidak akan melakukan prilaku SADARI lagi setiap bulannya.

Hasil penelitian ini tidak sejalan dengan penelitian dari Seftiani (2011)dalam hubungan pengetahuan dengan perilaku SADARI pada mahasiswa fakultas ilmu keperawataan Universitas Padjadjaran tahun 2011 sebagian besar mahasiswa dari 96 responden $56,52 \%$ melakukan pemeriksaan payudara sendiri dengan benar.

Begitupun sebaliknya mahasiswi dikategorikan baik dalam melakukan perilaku SADARI kemungkinan disebabkan karena mahasiswasebelumnya telah memiliki pengetahuan yang baik tentang pemeriksaan payudara sehingga mendorong perilaku mahasiswa untuk mencari informasi tentang langkah-langkah pemeriksaan payudara yang didapat pada petugas kesehatan dengan cara aktif bertanya saat penyuluhan dilaksanakan, selain itu mahasiswa dengan pengetahuan baik tentang manfaat SADARI memiliki motivasi dari dalam diri untuk menambah informasi tentang langkah-langkah pemeriksaan payudara dengan cara mengakses informasi baik media cetak maupun media elektronik.

Hal ini dapat menjadi faktor predisposisi mahasiswa memiliki pemahaman yang baik sehingga mampu mengaplikasikan dalam bentuk cara kerja pemeriksaan payudara dengan lengkap sesuai langkah-langkah pemeriksaan payudara. Begitu besarnya pengaruh pengatahuan dalam membentuk perilaku seseorang diperlukan dukungan oleh petugas kesehatan untuk lebih mensosialisasikan langkah-langkah pemeriksaan payudara melalui metode demontrasi secara langsung saat penyuluhan dan menggunakan bahasa yang mudah dipahami sehingga mahasiswa memiliki objek yang dapat diamati secara langsung guna 
membantu mahasiswa mengetahui secara jelas cara-cara melakukan pemeriksaan payudara.

\section{Hubungan Pengetahuan Tentang}

Kanker Payudara Dengan Perilaku

SADARIpada Mahasiswa Kebidanan Akbid Panca Bhakti Bandar Lampung

Pada tabel 3 diatas diketahui bahwa dari responden yang pengetahuannya baik, melakukan SADARI sebanyak $14(29,2 \%)$ responden dan sebanyak 1 (11,1\%) responden yang pengetahuan kurang yang melakukan SADARI. Dan Dari 34 (70,8\%) responden yang pengetahuannya baik tidak melakukan SADARI. Hasil uji statistik chi square dapat dinilai $\rho$ value $>$ dari $\alpha(0,420$ $>0,05$ ) yang artinya Ho diterima, tidak ada hubungan yang signifikasi antara pengetahuan tentang kanker payudara dengan perilaku SADARI (periksa payudara sendiri) pada mahasiswi Akbid Panca Bhakti Bandar Lampung Tahun 2019. Hal ini mungkin bisa disebabkan faktor lain yang dapat mempengaruhi suatu perilaku, diantaranya pengetahuan, kepercayaan, sikap, sumber daya (Notoatmodjo, 2007).

Penelitian ini sejalan dengan penelitian terkait sebelum nya yang dilakukan oleh Wantini dan Indrayani (2017) membuktikan bahwa tidak ada hubungan antara pengetahuan kanker payudara dengan perilaku SADARI dengan pvalue 0,458 .
Sejalan dengan hasil studi yang dilakukan WHO dan para ahli pendidikan kesehatan dalam jurnal kesehatan Putri (2011),terungkap memang benar bahwa pengetahun masyarakat tentang kesehatan sudah tinggi, tetapi praktik mereka masih rendah. Hal ini berarti bahwa perubahan atau peningkatan pengetahuan masyarakat tentang kesehatan sudah tinggi, tetapi prilakunya masih rendah. Hal ini berarti bahwa perubahan atau peningkatan pengetahuan masyarakat tentang kesehatan tidak diimbangi dengan prilakunya. Hasil penelitian diatas ternyata tidak sesuai dengan tinjauan teori yang menyebutkan bahwa perilaku yang didasari oleh pengetahuan akan lebih langgeng daripada perilaku yang tidak didasari oleh pengetahuan(Notoatmodjo, 2007).

Dari hasil penelitian ini juga terdapat perbedaan dengan penelitian terkait sebelumnya, yaitu penelitian Khasanah (2012) yang berjudul Hubungan pengetahuan remaja putri tentang kanker payudara dengan perilaku SADARI di SMP N 1 Tulang Bawang Udik Kabupaten Tulang Bawang Barat tahun 2012. Hasil uji statistik diperoleh nilai $\rho$ value sebesar 0,007 . Nilai $P$ value kurang dari 5\% (0,05). Dari penelitian ini ada hubungan yang signifikan antara tingkat pengetahuan tentang kanker payudara dengan perilaku SADARI.

Berdasarkan data diatas dapat dilihat selain pengetahuan ada beberapa hal yang bisa 
mempengaruhi perilaku seseorang, ini kemungkinan bisa menjadi alasan mengapa tingkat pengetahuan tidak berhubungan secara signifikan dengan perilaku SADARI.

\section{KESIMPULAN}

Berdasarkan hasil dan pembahasan diatas dapat disimpulkan bahwa Tidak ada hubungan yang signifikasi antara pengetahuan mahasiswatentang kanker payudara dengan perilaku SADARI. Bagi dosen pengajar mata kuliah Kesehatan Reproduksi diharapkan dapat mengembangkan materi dan media pada praktik tentang pemeriksaan SADARI contohnya video, sehingga mahasiswa lebih mudah mengingat dan mempraktikan kembali cara melakukan SADARI. Penelitian selanjutnya diharapkan dapat melakukan penelitian eksperimental berupa pre test dan post test tentang efektifitas video dengan prilaku SADARI.

\section{KEPUSTAKAAN}

Angrainy R. (2017). Hubungan Pengetahuan, Sikap tentang SADARI dalam Mendeteksi Dini kanker Payudara pada Remaja.Diperoleh dari https://ejournal.kopertis10.or.id

Depkes RI (2009). Buku Saku Pencegahan Kanker Leher Rahim dan Kanker Payudara.

Jakartahttps://agus34drajat.files.wordpr ess.com/

Khasanah (2012).Hubungan Pengetahuan Remaja Putri Tentang Kanker Payudara Dengan Perilaku SADARI di SMP N 1 Tulang Bawang Udik Kabupaten Tulang Bawang Barat.(Tidak dipublikasikan).

KeMenKes RI, (2015). Buletin Jendela Data dan Informasi Kesehatan. Jakarta
KeMenKes RI, (2019). Hari Kanker Sedunia. Jakarta

Notoatmodjo, S. (2007). Promosi Kesehatan dan Ilmu Perilaku. Jakarta. PT Rineka Cipta.

Notoatmodjo, S. (2010). Metodologi Penelitian Kesehatan.Jakarta. PT Rineka Cipta.

Notoatmodjo, S. (2014). Ilmu Perilaku Kesehatan.Jakarta. PT Rineka Cipta

P2TM Kemenkes RI. (2017). Deteksi Dini Kanker Payudara dengan SADARI dan SADANIS. Jakarta.Diperoleh dari http://www.p2ptm.kemkes.go.id/

Putri, A.E. (2011). Hubungan Tingkat Pengetahuan Dan Sikap Remaja Putri Tentang SADARI Terhadap Perilaku SADARI di MA KMI DINIYYAH Putri Padang Panjang.Diperoleh dari https://ojs.dinamikakesehatan.unism.ac.i d/

Rasjidi, I, (2010). 100 Question\& Answer: Kanker Pada Wanita. Jakarta: PT Elex Media Komputindo.

Sari, D. P, dkk. (2015).Hubungan Pengetahuan, Sikap, Dengan Tindakan SADARI Sebagai Deteksi Dini Kanker Payudara Pada Mahasiswi Di Fakultas Kesehatan Masyarakat Universitas Sumatera Utara. Diperoleh dari https://jurnal.usu.ac.id/

Sari,NK. (2017).Faktor-Faktor Yang Berhubungan Dengan Perilaku Pemeriksaan Payudara Sendiri (SADARI) Pada Mahasiswi Kesehatan Masyarakat Di Universitas Muhammadiyah Surakarta. Universitas Muhammadiyah Surakarta: FIK.Diperoleh dari http://eprints.ums.ac.id/

Seftiani(2011). Hubungan Pengetahuan Dengan Perilaku SADARI pada Mahasiswa Fakultas Ilmu Keperawataan Universitas Padjadjaran. Diperoleh dari http://jurnal.unpad.ac.id/ Wantini, NA \& Indrayani, N. (2017). Pengetahuan Tentang Kanker Payudara Dan Perilaku Periksa Payudara Sendiri (SADARI) Pada Remaja Putri Di Sma Negeri 1 Turi, Sleman,DIY.

Diperoleh darihttps://dspace.uii.ac.id/ 